\title{
4. Becoming Mary: Marian Devotion as a Solution to Gender-based Violence in Urban PNG
}

\author{
Anna-Karina Hermkens
}

\section{Abstract}

This chapter deals with how, in the urban setting of Madang in Papua New Guinea, Marian devotion is deployed in response to gender-based violence, including in the context of HIV. ${ }^{1}$ While providing insight into the lived religious experiences of Catholic women and, in particular, female members of the Legion of Mary, this chapter shows how women seek help from Mary and God in order to find a solution to the everyday violence they face. The experiences and perceptions described here reveal women's engagement in painful processes of self-analysis and self-transformation to hopefully adapt to and change their situation. In such processes, Mary is used as a role model.

\section{Introduction}

The association between Mary, the mother of Jesus, and violence may seem unlikely, but in Papua New Guinea (PNG), as elsewhere in the world, people turn to Mary in order to seek a solution for the problems they face (Hermkens 2007; Hermkens et al. 2009). ${ }^{2}$ This chapter deals with how, in the urban setting of Madang, Marian devotion is deployed in response to gender-based violence and HIV. In analysing the experiences and perceptions of female members of

\footnotetext{
1 I am indebted to all who have accommodated and assisted me with my research in PNG. Special thanks to Father Joe Forstner, the members of the Legion of Mary, and the Catholic Women's Association for assisting me with my research in Madang and Port Moresby. Thanks also to Father Jürgen Ommerborn, Philip Gibbs, Richard Eves, John Barker and Lawrence Hammar. Special thanks to all participants of the ASAO session 'Engendering Violence', and to Margaret Jolly, Christine Stewart and Carolyn Brewer for their insightful comments and suggestions on various drafts of this chapter. I thank the 'Netherlands Organization for Scientific Research' (NWO) for funding and the research programme 'The Power of Pilgrimage' at the Radboud University Nijmegen, Netherlands and The Australian National University and the Australian Research Council Laureate Fellowship, Engendering Persons Transforming Things for institutional support. This chapter is a shortened and revised version of an article which was published in the journal Oceania $78(2)$ (July 2008):151-67. I thank the editorial board of Oceania for permission to republish it in a revised form.

2 While in this paper it is shown how Marian devotion helps women to cope with violent environments, other cases show that Marian devotion can be used as a powerful and subversive tool to challenge existing economic, social and church hierarchies (see for instance Ram 1991; Margry 2009; Hermkens et al. 2009).
} 
the Legion of Mary we must relate this to the current debate on Christianity in PNG (e.g. Robbins 2004; Jebens 2005), and to earlier calls for a more intensive anthropological investigation of the experience of Christianity by Melanesians (e.g. Barker 1990: 9; 1992).

The influence of Christianity in PNG is profound. Christian values are part of the country's constitution, which states that 'We, The People Of Papua New Guinea ... pledge ourselves to guard and pass on to those who come after us our noble traditions and the Christian principles that are ours now.' Moreover, almost all Papua New Guineans say they are Christian and political discourse is saturated with Christian rhetoric and references (Gibbs 2005). In urban areas, the abundance of churches, evangelical rallies and the popularity of gospel music testify to the popularity of Christianity and its pervasiveness in daily life.

The majority of people living in the urban areas of Madang Province are Catholic (35\%), followed by Evangelical Lutheran, Pentecostals and Seventh Day Adventists (NSO 2002). ${ }^{3}$ The predominance of Catholicism in Madang Province is also visible in Madang town, which is the Papua New Guinean cradle of 'The Legion of Mary', a lay Catholic organisation founded in Dublin, Ireland in 1921. Spread throughout the world, its members give Glory to God 'through the holiness of its members developed by prayer and active co-operation in Mary's and the Church's work.' ${ }^{4}$

All over the world, the basic unit of the Legion of Mary is called a praesidium. The secretary and president of each praesidium report to their council, their curia, who in turn report to their regia, which falls under a consilium. In PNG there are two regiae, one on the mainland of PNG and one in the islands of PNG. These regiae work with the consilium in Ireland. The regia on the mainland of PNG has its headquarters in Madang and looks after fifty-four curiae, making Madang the centre of all legion activities in the country.

Each week, both male and female members of the Legion of Mary in Madang gather for a praesidium meeting, intermingling prayer with reports and discussion. In addition, each member is assigned work to be performed during the week, which is done in co-operation with another member. Mostly, this implies visiting sick people in Madang hospital, but sometimes legionaries also visit people in prison or others in need of spiritual help. For the women I interviewed, the weekly legionary meetings and assigned works constitute only part of a Catholic schedule. In addition to the legionary meetings and

\footnotetext{
3 According to the Catholic Church in Papua New Guinea, the number of Catholics in Madang Province is larger. In 2004, reportedly 142,000 people (49.8\%) were Catholic (Archdiocese Madang, Statistics http:// www.catholic-hierarchy.org/diocese/dmada.html, accessed 2 November 2011).

4 Concilius Legonis Mariae, The Legion of Mary, 2010, online: http://www.legion-of-mary.ie/, accessed June 2009.
} 
related duties, there are other activities: Sunday mass and subsequent meetings with legionary members and other Catholics, weekly evening prayer groups, visiting evening masses in the Madang area, and occasional Church work, such as fundraising, cooking and cleaning.

From the late 1970s, Father Ernest Golly was the Legion's national director. In addition to translating the Legion's handbook, he published several dozen pamphlets on Marian devotion. Besides being the national director, he was also the spiritual director of the mainland regia and parish priest of Jomba parish in Madang. ${ }^{5}$ In exercising these functions, he also largely controlled the practices of the Legion of Mary in Madang and the PNG mainland, and how Catholicism, and in particular Marian devotion, was practised in Jomba parish and beyond. ${ }^{6}$ In Fr Golly's view, devotion to Mary was an essential part of Catholicism and Christianity. Moreover, when dealing with issues such as HIV and domestic violence, faith in God and devotion to Mary are both crucial considerations.

This chapter focuses on the experiences of Catholic women and, in particular, of female members of the Legion of Mary. It offers insights into how Marian devotion is practised and used by individual women in seeking a solution for the violence they face. In what follows, I offer an overview of the various forms of violence Papua New Guinean women confront, and how these simultaneous personal acts of violence and structural 'states of violence' shape their individual everyday experiences. $^{7}$

\section{Acts and states of violence}

My daughter was working as a teacher in a remote area. On their way back their truck was looted and all the female teachers, including my daughter, were dragged out of the truck. The male teachers were trying to help them but there were too many raskols [TP: roving band of criminals]. They pulled my daughter aside and she was raped. When she told me, I cried. At that time, my husband came home and found us

\footnotetext{
5 Father Golly passed away in May 2010.

6 Although Fr Golly had a huge influence among Catholics (both legionaries and non-legionary members) in Madang, he was certainly not representative of all Catholic priests in PNG. In Madang alone, there are several Church officials who do not concur with Fr Golly's point of view and the way that he used his fire and brimstone theology to counsel his legionary and Parish members. However, he faced little or no interference from the Catholic community and his superiors.

7 Women (and men) turn to Mary and God to seek guidance, help and empowerment in addressing and redressing violence. Although I also interviewed male members of the Legion of Mary, and Catholic men in general, focus in this chapter is on how Legionary women live their devotion to Mary and cope with genderbased violence in particular. The men I interviewed did not approve of domestic violence. Some used devotion to Mary to reduce and control their own feelings of anger. All were of the opinion that the husband is the head of the family.
} 
crying. He started hitting me, beating me, saying it was my fault that my daughter was crying. My daughter then started crying because of me. I asked him to stop so I could take care of our daughter. He stopped and I took her to the hospital; we were so afraid of AIDS. She had a boyfriend and we did not know how he would react upon my daughter having been raped. Fortunately, the test was negative; no AIDS. Her father did not know what had happened to her. He just left us for three years. So, this is what we as women are facing! (Interview with Alice: Madang 2005). ${ }^{8}$

This story was told to me by Alice, a woman of forty-nine years - mother of seven children, grandmother of five and member of the Legion of Mary. The story recounts not just Alice's experiences, but her reflection on the different forms of violence that women in PNG might face. The violence addressed in the previous narrative is pervasive (Kleinman 1997), comprising both 'acts of violence' and 'states of violence' (Mounier in Brown 1987: 34). Acts of violence are violent practices such as beating or robbing someone, while, according to Robert Brown (1987: 34-5), 'states of violence' refer to violence that is so part of the given social order as to be institutional or structural.

The several acts of violence that are addressed in Alice's narrative are criminal violence (including being held up and robbed), sexual violence (rape by strangers), domestic violence (physical beating and emotional abuse by the husband) and violation of health (risk of being infected with HIV). In Alice's and other women's experiences, such acts may occur on public streets, in the community, in domestic settings, at work and even in institutions such as the Church.

Alice's experiences with different forms of violence are not unique. As argued by Christine Bradley (2001: 2), 'the majority of adult women of Papua New Guinea have been physically assaulted by their husbands, forced to have sex with them, or have been raped or sexually assaulted by other men.' Statistics also reveal that domestic violence is the most dominant form of sexual violence. Surveys conducted in the mid-1980s showed that 67 per cent of rural women and 56 per cent of urban women have been hit by their husbands (Toft 1985: 14). ${ }^{9}$ In my own research among Catholic women in Port Moresby and Madang from August 2005 till February 2006, I found that twenty-two of the forty-two female members of the Catholic Women's Association and the Legion of Mary that I interviewed reported having experienced domestic violence. ${ }^{10}$

8 Although the key informants of this article emphasised they wanted to be mentioned by their full names, I have instead decided on protecting their identities by using pseudonyms.

9 The PNG Law Reform Commission conducted research on domestic violence between 1982 and 1992. The final report (1992) showed that 70 per cent of all women in PNG had been beaten by their husbands.

10 From August 2005 until February 2006 I did fieldwork in, amongst other places, Port Moresby and Madang concerning Marian devotion and domestic violence. In addition to five interviews with Christian 
A census conducted in the 1980s revealed that marital fights are mainly the result of alcohol, money and jealousy, followed by problems with the children and violence perpetrated by the husband (Conway and Mantovani 1990: 12122). Domestic violence was attributed to men's drinking, gambling and bad temper, and to women's behaviour, such as 'gossiping', going out alone, not performing their 'duties' and talking to strangers of the opposite sex (Conway and Mantovani 1990: 127). In more recent studies, alcohol is frequently mentioned as a precipitating factor in family problems (see for example Banks 2000: 89). The perceived 'misbehaviour' of women, however, suggests that there is an underlying cause for domestic violence, namely male domination and men's fear of losing control over women. Alice's case, as well as others, shows that in general violence against women occurs when 'men perceive they have lost control over women; when women are perceived by men to have breached certain expectations of conduct; and when there are underlying prior injuries within the family' (Banks 2000: 95). In particular, continuing presumptions of male dominance (Kidu 2000: 30; see also Macintyre, Ch. 8) and gender-based hierarchies seem to fuel violence towards girls and women (Eves 2006: 26). ${ }^{11}$ This suggests that violence experienced by Alice and other women is actually part of what Emmanual Mounier referred to as 'states of violence' (Mounier cited in Brown 1987: 34), violence which is institutional and structural. Other scholars of PNG suggest that gender violence is a form of structural violence. Martha Macintyre (Ch. 8) argues that in PNG violence against women is an expression of deeply-entrenched political discrimination against women at personal, local and national levels.

Moreover, gender-based violence can lead to another form of structural violence: the endangering of women's health. One of the major problems PNG is facing today is an HIV epidemic (Butt and Eves 2008). Some of the reasons for this crisis and the increasing rate of infection among women involve both gender-based violence and growing impoverishment which ensure increased vulnerability to the virus (Jenkins 1995: vii). This risk is exacerbated by the fact that women have hardly any means of protecting themselves against HIV. While the government advocates the use of condoms, most women are unable to negotiate

women who are not affiliated with particular religious groups, interviews were conducted with women belonging to the Catholic Women's Organisation (CWA) in Madang (19 women), and with people belonging to the Legion of Mary in Madang (10 women and three men) and Port Moresby (13 women). Of the nineteen CWA women, sixteen reported that they had been beaten by their husbands, while among the Legion of Mary members in Madang and Moresby six women (three in Madang and three in Port Moresby) had faced domestic violence. The women I interviewed belong to different tribal backgrounds. Moreover, they belong to different socio-economic strata, although none of them lives in the so-called squatter settlements. The majority could be labelled as middle-class with a few women belonging to the lower-class and one woman to the upper-class. 11 Various studies have attempted to analyse the 'culture of violence' in PNG (Bradley 1994, 2001; Dinnen 1997; Dinnen and Ley 2000; Jenkins 1995; Kidu 2000; Toft 1985; Zimmer-Tamakoshi 1990, 1997, 2004). In addition to existing gender hierarchies and male dominance, factors that have been identified in relation to sexual violence are: economic impoverishment and increase ng criminality, changing gender relations, as well as a decline of morality, especially in urban settings. 
for safe sex, and so many are unable to use them or 'Just say "No"' (Hammar 1999: 151; 2007: 79). In addition, especially among Catholics, there is a strong belief that condoms interfere with God's divine will through contraception, and in HIV awareness condoms are actually spreading HIV as they encourage sexual promiscuity (see also Wardlow 2008). ${ }^{12}$ Julie, who works at the Archdiocesan HIV/AIDS office, is of a similar opinion, urging her clientele to instead practise the calendar or rhythm method or abstinence and faithfulness. Yet her own experiences show that this might be difficult to achieve. Julie's husband had unprotected sex with others and she could not refuse him. So, it seems that women, and especially Catholic women, are unable to protect themselves against being infected with HIV and other sexually transmitted diseases (STDs, see also Hammar 2007: 79). Moreover, once infected, women can find it difficult to obtain help because husbands and families may prevent women from seeking medical attention as they do not want their wives, sisters and daughters to be seen as 'sexual beings or to admit that they have been affected by male relatives' (Hammer 1999: 50-51).

The different forms of violence endured by Alice, Julie and other PNG women result in, and are the result of, acts and states of violence that effectively structure their everyday lives (Schmidt and Schröder 2001: 1). In Alice's experience, the domestic violence she endured for twenty-seven years was not only physical. The fact that she and her husband were always arguing is as much a part of her perception of the violence of her everyday life as the physical abuse. In a similar way, her husband's regular adultery and his disrespect towards her amplified Alice's sense of having to endure a lifetime of violence. The effects of this violence on her children contributed to Alice's own sense of suffering. Alice is convinced that the violence that was part of her married life resulted in her first daughter's sudden death. But, she feels that she is responsible for her daughter's death. This guilt results in an all-pervasive sense of suffering, which is in itself a form of everyday violence (Kleinman 1997). Women thus not only have to cope with violent acts which are both physical and emotional assertions of power by

12 This negative perception towards condoms is, however, not characteristic of the whole of PNG. Lepani (2008), for instance, shows the positive attitude that the Trobriand people have towards condom use and how they conceptualise HIV in terms of their socially-constructed realities, as enabling the transformation of highrisk sexual practices (Lepani 2008: 266).

On 21 November 2010, Pope Benedict XVI, in Peter Seeward's book, Light of the World: The Pope, the Church and the Signs of the Times, appeared to endorse condom use by male prostitutes when he said: 'There may be a basis in the case of some individuals, as perhaps when a male prostitute uses a condom, where this can be a first step in the direction of a moralization, a first assumption of responsibility, on the way toward recovering an awareness that not everything is allowed and that one cannot do whatever one wants. But it is not really the way to deal with the evil of HIV infection.' Church commentators were quick to explain that while Pope Benedict XVI was talking of male prostitutes and homosexual acts, he was not discussing sex between married heterosexual people or sex between a man and a woman. Indeed, as Scott P. Richert (2011) explained, 'Pope Benedict did not change one iota of Catholic teaching on the immorality of artificial contraception.' 
men (Schmidt and Schröder 2001: 1), but also with their own embodied state of violence suffused by their suffering. Such everyday violence is both confirmed and enhanced by media coverage.

Almost every day, newspaper reports inform Papua New Guineans, as well as the world, that PNG is a violent society. In addition to violent burglaries and hold ups, sexual violence against women and girls appears to be endemic, and, according to some reports, even increasing. For example, Papua New Guinea's daily newspaper, the Post-Courier, stressed its role in representing domestic violence stating that 'family violence is PNG's national shame'. In its 4 June 2009 editorial, the editor stated:

Family violence in Papua New Guinea is a story that needs to be told, over and over. For the consequences of this crime against people are huge. That is why we make no apologies for telling you of the tragic event which unfolded in Port Moresby this week as the police family and sexual violence office continued its probes into complaints by victimised women and children (Editorial 2009).

The regular front-page news coverage and the activities of both government and non-government organisations concerning the occurrence of sexual violence seem to have created a concern which Anou Borrey (2000: 105) termed a 'social panic'. While Borrey puts sexual violence in PNG in perspective, the fact is that especially in Papua New Guinean towns, women do live in a state of 'low level terror' (Macintyre in Bradley 2001: 2). This state of terror is exemplified by Elaine, a forty-three-year-old teacher and mother of four children living and working in Madang:

When my husband is away for travel I protect myself by hanging the rosary at the doorway so Mary will protect me and the children. I am very scared when my husband is away, but we are always all right as the rosary makes sure Mama Maria is with me during such times.

\section{Seeking solutions}

To address this 'state of terror' occasioned by gender-based violence, the PNG government conducted large-scale research through the Law Reform Commission in the 1980s (Toft 1985a, 1985, 1986; Toft and Bonnell 1985). Despite these reports and more recent studies (AusAID 2007 preliminary; AusAID 2009) however, the government has been slow to respond and take adequate measures (Bradley 2001). Only recently has the government supported public campaigns in which gender-based violence and the relationship between violence and HIV have been addressed. These campaigns are mainly the initiative of foreign AID 
donors or NGOs. Deploying huge billboards, advertisements and posters, the official message is clear: Real men do not harm women and girls; and if men and women want to have sex they should use condoms. Likewise, organisations such as the Country Women's Organisation in Madang and the Madang Family and Sexual Violence Committee have launched poster campaigns against domestic and sexual violence by addressing men's lack of respect towards women. However, the success of these campaigns is debatable, especially as posters are frequently 'misread' (Eves 2006: 55, 88-89; Hammar 2008; McPherson 2008).

In contrast to poster and action drama campaigns (see McPherson 2008) that often seem to fail, the impact of religious movements in addressing morally threatening issues such as violence and HIV seems to be enormous (see for example Eves 2003, 2008; Hammar 2008). With regard to HIV, the Catholic Church strongly objects to the government's express policy of advocating condom use as the solution for HIV. The Church, its clergy and many of its members strongly oppose the use of condoms, first, because it allegedly encourages promiscuity and thereby seems responsible for spreading HIV, and second, because condoms interfere with the divine plan of God. Fr Golly, who, as we have seen, was both the national and spiritual director of the Legion of Mary in mainland PNG and priest of Jomba Parish in Madang, was, until his recent death, very outspoken against condom use. As reported in the National newspaper:

During a Jesus March in Madang in May 2006, Parish priest Fr Golly spoke against fornication and sex before marriage. He told the large group that 'the only sure way of avoiding HIV/AIDS was to use Abba, a Hebrew term meaning 'father'. ABBA is the acronym and stands for 'abstinence, be faithful, be faithful and abstinence.' In his concluding remarks, Fr Golly said condoms were not of any help in preventing this deadly disease and should not be used as an alternative (National 29 May 2006).

In an interview I had with Fr Golly (Jomba Parish 2005), he explained his attitude towards condoms as follows:

God does not allow us to use condoms. We are not animals! People should use the calendar method. This is the way of God. Condoms are the Devil's work! The only country where AIDS is decreasing is Uganda. They took the way of the Lord! ${ }^{13}$

Julie, who works at the Archdiocesan HIV/AIDS office, has a similar view to that of her spiritual director, Fr Golly, but at the same time is pressured to follow, to a certain extent, the point of view of the government which advocates condom

13 The 'calendar method', referred to by Father Golly, is similar to the rhythm method of contraception. 
use. Caught between religious norms and values and government policy, she promotes the ABCD (abstinence, be faithful, condoms, delay). ${ }^{14}$ However, when asked to explain her standpoint she states:

When a woman comes for advice regarding adultery committed by her husband, I talk: 'You are in danger. You must take good care of your body and talk with your husband.' I tell her where to get a blood test. I do not tell her to use condoms, because maybe they do not use it well, get AIDS and blame me. The Catholic Church does not approve of condoms. This is to encourage moral understanding of sex. One must practice delay, abstinence, get married and stick together. 'Condoms $i$ stap, sapos yu animal, yu usim!' [TP: Condoms exist: if you are an animal you use condoms!] (Julie, Madang 2006).

People working in healthcare and hospitals often juggle their religious attitudes and official government rhetoric (see Wardlow 2008). For example, Anna, a Catholic nurse working in Madang hospital, is strongly against the use of condoms and told me that despite the hospital's policy of promoting condoms, she advises her patients not to use them.

I object to the use of condoms, it is my faith. Because my faith in the mother. I tell my nieces, keep yourself Holy for Him. Do not use medicines or injections to intercept the baby. I work in the hospital and I do not want to go against the government but I speak from my faith. It is our body, It is God's way for us to have a baby or not. Condoms interrupt the plan of God (Anna, Madang 2005).

Such attitudes of hospital workers in privileging Church policy over government policy are also reported by Holly Wardlow in her study of HIV among the Huli. The hospital workers that Wardlow interviewed depicted condoms as encouraging illicit sex and as being useless in preventing HIV infections (Wardlow 2008). According to Naomi McPherson in her study of HIV awareness campaigns in the Bariai district in West New Britain, the church is also responsible for exacerbating the HIV problem in stressing the sinful nature of promiscuous sex, making condom use even more out of the question (Dundon 2010; Wardlow 2008: 196-97; McPherson 2008: 244; McPherson, Ch. 1).

Importantly, the link between 'immoral' behaviour and HIV implies that those who are infected have somehow called down misfortune on themselves through immoral behaviour. McPherson notes that most of her informants believe that 'it [HIV] is God's punishment for immoral behavior' (2008: 244). In fact, in some areas of PNG, HIV is not only seen as an aspect of moral decay, but as

14 The abstinence here links directly to the 'Abstinence', Be Faithful' and 'No Condoms' policies associated with USAID during the Bush era (Butt and Eves 2008). 
actually marking the approach of the end of the world within the framework of apocalyptic Christianity (Eves 2003). Among members of the Legion of Mary, I did not encounter such apocalyptic views of the 'end-times', but the general perception was that HIV was still a sign of a general moral decay that is believed especially to affect urban areas like Madang.

To confront and change 'immoral' behaviour which allegedly results in illnesses such as HIV, many people look for spiritual help. Certain Catholic healing ministries and individual healers make use of statues of Mary and other Saints, holy water, prayer and the rosary to free people from demonic possessions and illness. Pamphlets with personal accounts of having been healed from AIDS, of having overcome alcohol abuse and of having resolved family problems through faith in God are distributed widely. One such pamphlet reads:

Are you happy? Sick? Suffering? Searching for God? Come and hear God's salvation message about miraculous healing testimonies of: HIV/ AIDS, other diseases, broken marriages, old habits (Revival Centres of Papua New Guinea 2005).

This faith in divine healing is grounded in both Christian doctrine and locally established concepts about the nature and purpose of healing as well as of sickness in general. The two streams of knowledge reinforce the belief that illnesses like HIV are not just medical but are also social and moral phenomena.

The question is: how do Catholics and in particular Catholic women prevent themselves from getting infected? Faced with a high probability of being a victim of rape and/or domestic violence (as are all other Papua New Guinean women), since the use of condoms is not an option for them, they seem to be especially vulnerable to HIV infection. As Julie said,

The time I was married, I did not know about AIDS. I was teaching at the Family Life Office, so I should have realised. But I thought I was safe because I was married. Only after my husband left us I realised this danger. Just recently, when we did this program about voluntary testing, I had my blood tested. I got worried ... but fortunately, God has been protecting me.

My husband did not use condoms when having sex with me. I did not either. I do not think he used condoms when sleeping with other women. So I say: 'Thanks Lord! You protected me!' (Julie, Madang 2005).

Julie's narrative indicates that Catholic women feel protected because they are married, even if they know that their husbands have extramarital relationships. 
Moreover, as indicated by Julie, these women are convinced that God will protect them, as long as they have a strong faith and lead a good Christian life (Hammar 2010).

Among Catholics in Madang, not only belief in God, but also devotion to Mary is believed to prevent one from getting infected. In order to stay on the right path, Mary is promulgated as a role model, thereby on one hand preventing infection and, on the other, enabling salvation. For example, in the Post-Courier (December 29, 2004) medical doctor Thomas Vinit (Madang Hospital) argues: 'Let us use good models that portray chastity and purity, such as the devotion of the Virgin Mary' in order to address the root of the HIV problem in PNG, which are 'moral and socio-economical problems' ${ }^{15}$ This emphasis on using Mary as a role model in order to solve moral and social problems is also instrumental in how Catholic women deal and cope with various forms of domestic violence. Confronted with domestic violence and divorce in an environment where this is seen as sinful, many Catholic women like Alice and Julie seek spiritual guidance; finding solace in prayers directed to Mary and gaining strength by using Mary as their example.

\section{Mimicking Mary and the power of self- transformation}

Sometimes I wonder: how did I survive all this? I thank God and our Lady, she is my role model: a simple, humble woman (Alice, Madang 2006).

All over the world, Mary's celebrated virtues of humility, obedience and faith are appropriated by women and inscribed on women's bodies. Especially among members of the Legion of Mary, this use of Mary as an example, as a 'role model' whose virtues must be aspired to, is propagated. The Official Handbook of the Legion of Mary (Concilium Legionis Mariae 1993: 12) describes Mary's virtues, which constitute its members' aspirations, as follows:

The Legion of Mary in particular aspires to Mary's profound humility, Her perfect obedience, Her angelical sweetness, Her continual prayer, Her universal mortification, Her altogether spotless purity, Her heroic patience, Her heavenly wisdom, Her self-sacrificing courageous love of God, and above all Her faith.

15 Dr. Vinit, while strongly opposing condoms, is now head of the Lifestyle Diseases Division of the National Department of Health (Hammar 2007: 75). 
Mary the 'Immaculate Conception' is the Legion's worldwide leader. The image of Mary crushing the serpent's head symbolises that Mary is the Immaculate Conception: the Divine Maternity born without sin, 'the crushing of the serpent's head in redemption, and Mary's motherhood of men' (Concilium Legionis Mariae 1993: 20). As a legionary, members are expected to submit to Mary completely: 'the legionary distrusts the promptings of his [sic] own inclinations and in all things listens intently for the whisperings of grace' (Concilium Legionis Mariae 1993: 30). In fact, 'the giver places himself [sic] in a condition equivalent to that of a slave possessing nothing of his own, and wholly dependent on, and utterly at the disposal of Mary' (Concilium Legionis Mariae 1993: 37). In addition, the members of the Legion are also perceived as Her 'warriors'. Based upon Genesis 3:15, the Legion perceives itself as Mary's warriors against sin that turns to Mary's enmity with the devil as a 'source of confidence and strength in its warfare with sin' (Concilium Legionis Mariae 1993: 20). The legion is thus perceived as an army, which 'throws itself in the warfare of Christ' in which its members submit themselves 'to His glorious commands'. Being both slave and warrior is actually seen to empower the legionaries. As the handbook states: 'The imitation of Mary's humility is both the root and the instrument of legionary action' (Concilium Legionis Mariae 1993: 27).

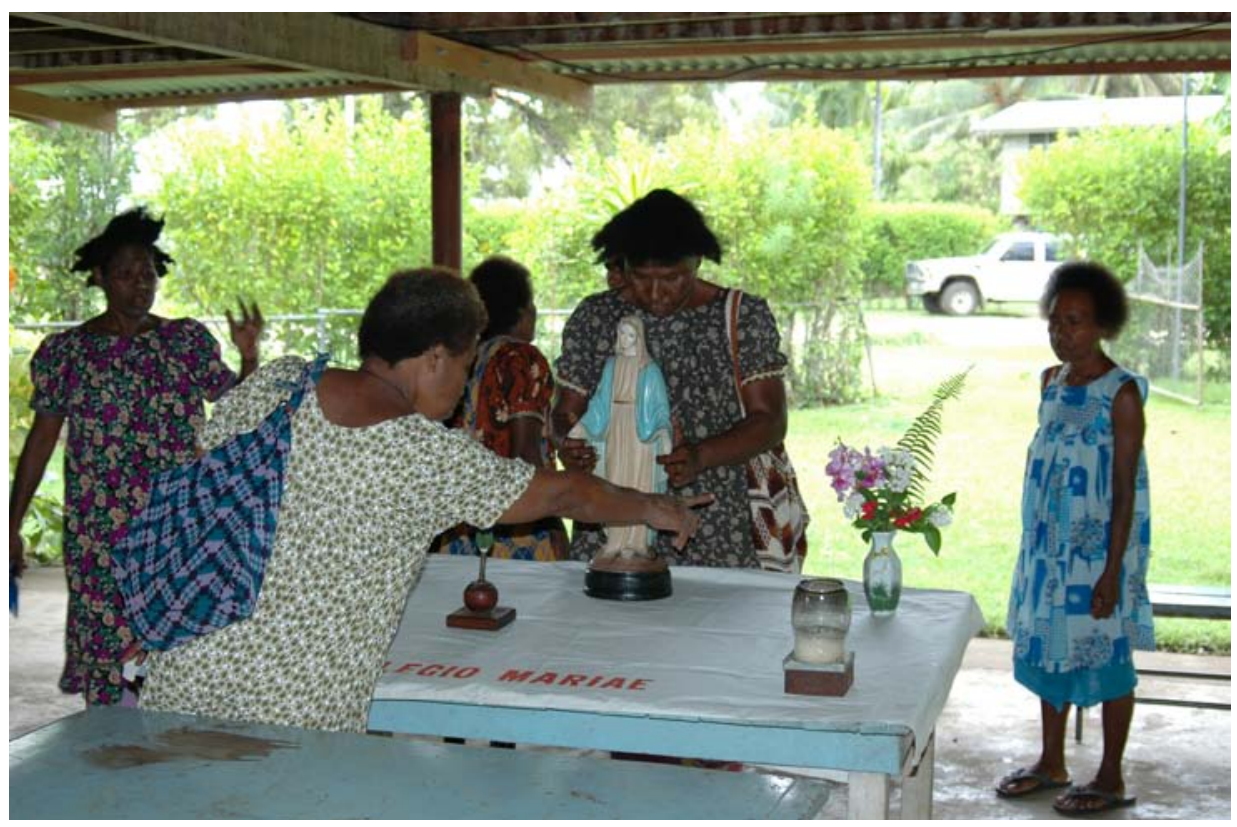

Figure 7. Legionaries in Madang preparing for a meeting, placing their leader the 'Immaculate Conception' on a make-shift altar, 2006.

Photograph by Anna-Karina Hermkens. 
As an example, Mary teaches legionaries to aspire to qualities such as humility, patience, faith and obedience-characteristics that are ascribed to Mary in particular by the Legion of Mary and the Catholic Church in general (Ruether 1993; McLauglin 1974). As Alice observed:

Mary is a model to me: Pasin bilong en, em daun passin [Her style/fashion is humility]. Understanding and following Mary, brought understanding about my own self. Now, I believe in humility and the truth. I find peace in not making others angry, but helping them instead.

When asking other female members of the Legion of Mary in both Madang and Port Moresby what role Mary plays in their lives and in their families, I encountered similar expressions. For many, Mary is their spiritual mother who guides and protects them and whose virtues of peace, humility and caring, are loved and admired. Theresa, a sixty-three-year-old auxiliary member of the Legion of Mary, suggested:

Mary is an example to all women. She is the mother of the Holy Family and as a woman and a mother she understands the problems and hardships that we [women] go through. She is the comforter (Theresa, Port Moresby 2005).

But Mary is not just an example to women in the sense that they admire Her and seek Her out as their spiritual mother. The women I interviewed actually aspire to be as Mary. By 'becoming' Mary they try to come closer to her, and consequently, to God. This mimesis is achieved by praying the Rosary. Furthermore, members of the Legion of Mary aspire to achieve Mary's virtues by dressing in blue. In this context, mimesis is not simply 'imitation'. Mimicking Mary implies not only that a spiritual connection is achieved, but that 'a palpable, sensuous connection between the very body of the perceiver and the perceived' is created (Taussig 1993: 21). This bodily connection is an important dimension of any form of belief (Ram 2005) and crucial in women's sense of self-transformation and spiritual passage. According to many of the women I interviewed, becoming like Mary meant internalising Mary's virtues, transforming their bodily behaviour and, consequently, changing their lives. As explained by teacher Elaine:

Mary is a very good example. I follow her footsteps, as she understands everything. She changed my life. To me, I am very impatient. I get cross easily because I am so impatient. I often get cross with my husband, who is a quiet man. Then we started to pray [the Rosary] and I realised I could not be impatient to my children and husband anymore. Also in my work, I have to be patient. My husband realises I have changed. I am trying to be a good mother, instead of screaming and beating them. 
Now I do not do it that way. Thank God I realise this now. Maria is my example. I admire her motherly care for her children, her humility and humbleness, and her love for Jesus. She is a woman of prayer. I ask her what to do and follow her.

What is striking in such narratives by women in their aspirations to be like Mary is the emphasis on self-transformation. As articulated by Elaine and others, Mary provided insights into their bad habits, which they subsequently tried to change. According to Alice and Julie, Mary's qualities as a humble woman showed them how they had failed in their own marriages. By changing themselves, by changing their own anger into humility, they did, alas, not change their husbands, but they received peace and acceptance of their situation as it was at the time. For many of the other abused women I spoke to, this emphasis on self-transformation was not just the only way to change their situation, but also the way to change their husbands.

Faced with domestic violence or other problems, the most effective way to achieve results is to focus on what can be changed: oneself. To scrutinise oneself and to work and turn oneself into a good Christian wife is, for most women, the most accessible way to change their situation. In this, women attribute power and agency to themselves. As argued by Griffith (1997: 166) in describing published narratives of Aglow women in the US, 'women centre their narratives on their own capacity to initiate personal healing and cultivate domestic harmony.' This personal power is, according to Griffith, encoded in a 'doctrine of submission'. In women's narratives described by Griffith (1997: 166), 'good results will follow a wife's willing acquiescence: once women's attitudes are transformed and they accept their submissive roles, their husbands also become happier and more benevolent.'

Such a doctrine of submission is also visible in Catholic women's narratives, wherein submission is not only to Mary and to God, but also to one's husband. As Mary, president of the Legion of Mary in Madang, expressed: 'Mary is our role model. She is obedient to God. So we submit to our men. They are the head of the family.' Others equally stressed Mary's role in providing them with a good example of being a good Christian woman who submitted to both God and her husband. As one of the Legion's members stated: 'I imitate Mary's humility, Her faith, praying, sacrifices, obedience. Obedience to my husband and towards religious duties.' Importantly, this religious doctrine of submission resonates strongly with gender hierarchies in PNG where, in general, male domination is the status quo and women are expected to submit and be obedient to men (see also Macintyre, Ch. 8). As such, religious doctrine, just like kastam, emphasises male domination, empowering women to submit, rather than resist, and thus promoting domestic harmony. This union of Christian and cultural values results in a powerful doctrine of submission which is, despite growing 
opportunities for women to divorce and circumvent cultural values of female submission, difficult to resist. Women's social and religious environment keeps re-inscribing woman's responsibility in attaining domestic harmony and being obedient to both husband and God. Failing to do so means failing socially, religiously and personally and can lead to social isolation and even depression, as Alice and Julie discovered. Mary provides women with a shining example of how to fashion themselves into good Catholic wives in PNG.

Importantly, mimicking Mary not only involves changing women's attitudes. It involves the transformation of one's self. The emphasis on self-transformation into the image of Mary actually calls for the submission and suppression of the self. As stated in the Handbook of the Legion of Mary: 'The legionary, in turning towards Mary, must necessarily turn away from self' (Concilium Legionis Mariae 1993: 30). The 'humble Virgin's heel' not only crushes Satan, but it also crushes 'the serpent of self with its many heads'. These are the heads of selfexaltation, of self-seeking, of self-sufficiency, of self-conceit, of self-love, of selfsatisfaction, of self-advancement and of self-will (Concilium Legionis Mariae 1993: 30). Yet paradoxically, this Christian rhetoric which calls for the denial of the self also emphasises the self.

\section{Negation or suppression of the self?}

As argued by Joel Robbins (2005), Christianity focuses on the subject, on the self. More precisely, 'Christianity forces oneself to identify with one's own inferiority, one's sinful nature.' It teaches people to look inward and to alter their notions of subjectivity as something to be regulated (pp. 46-47). Focus is thus on the subject, on the formation of self. Richard Eves makes similar observations in his study on modernity, morality and illness among the Lelet people in New Ireland. By converting to Evangelical Christianity, Lelet converts 'create a new self, a self-refashioning' in which they seek to cultivate a new Christian way of being (Eves 2005: 28).

In contrast to Robbin's (2002: 311) claim that Christianity increases individualism, Mark Mosko (2010) stresses the personal partibility in Melanesian Christianity. Relying heavily on Marilyn Strathern's insights on Melanesian 'dividual' personhood, which is the product of relations with other persons, Mosko argues that the sociality of (Melanesian) Christianity is not individualistic in the sense of bounded personhood but consists instead 'in elicitive transactions between dividual persons, human and spiritual' (p. 222). My experience with Catholic women in Madang is that both representations of personhood, individual and relational (or dividual) coexist, albeit sometimes in conflictual tension (see also Wardlow 2006: 19-20). The Catholic Church, and in particular the rhetoric 
of the late Fr Golly, continually confront the legionaries and parish members with their sinful nature, which calls for self-reflection and, importantly, selftransformation. In addition to this emphasis on the individual self, this rhetoric also impacts on women's relational and dividual personhoods as it promises women that they can change their husbands by giving up their sinful selves and giving themselves to Mary and God - thereby receiving divine help and blessings.

The women I spoke to in Madang and Port Moresby engage in similar processes of self-refashioning. Women are encouraged to monitor their behaviour, to stop cursing and arguing with their husbands, to be patient and obedient. By internalising and re-enacting Christian values through the image of Mary, their focus is thus on self-discipline (see also Robbins 2005: 51). In Michel Foucault's terms, these women engage in 'self-surveillance' (Foucault 1997). Selfsurveillance is usually understood as 'the attention one pays to one's behaviour when facing the actuality or virtuality of an immediate or mediated observation by others whose opinion he or she deems as relevant' (Vaz and Bruno 2003: 273). In this case, one of the main observers of women's behaviour is Mary-an inescapable omnipresence.

So Mary becomes a powerful icon around which women rework (part of) their identities and transform themselves into ideal Christian women through selfsurveillance. In Madang, the doctrine of religious and domestic submission that is adhered to is empowered by Christian rhetoric which demands obedience and, especially, submission from the wife, both in her relationship towards God and towards her husband. These values are propagated through books concerning Mary (for example Hahn 2001) which are extremely popular among Marian devotees, and Christian booklets that are published and distributed in PNG (for example Fountain 1984; Malins 1987; Sala 1999). Moreover, these values are part of the rhetoric and advice given by legion members as well as by its erstwhile spiritual director, Fr Golly:

I was told to pray, pray. My spiritual director [Fr Golly] told me to find my weakness and perform. He told me: 'You go back to your husband!' I cried. I cried and I prayed. I was so scared to go back. But I went back, and ... I was again abused. I went back to Father Golly and I told him that I valued my life. Who is going to take care of my children? But he was looking at my marriage, not at my own safety.

In 1991, for six months, I did not give myself to my husband. Father Golly told me to break my heart of stone. And I prayed to do this and I did it, but without love, to satisfy my husband (Alice, Madang 2006). 
Marie Griffith(1997) argues that personal power is intrinsic to women's submission as this enables them to change their situation by changing themselves. However, Griffith fails to offer insights into how women's reworking of their identities is actually a very difficult and painful process, and may not elicit a parallel self-fashioning in the husband, who may continue to act in aggressive or other difficult ways or even, like Alice's husband, desert the family. For women like Alice, the effort of becoming an ideal Christian woman was painful and the price paid was high.

\section{The power of Mary: Re-enacting normative violence?}

This chapter has addressed the place of Mary in the negotiations of a particular group of urban Catholic women with various forms of violence. As shown, women like Alice and Julie not only have to cope with violent acts such as rape, but also with 'states of violence'. These states of violence are linked to the dynamics of the urban context in which morally troubling issues such as gang violence, criminality, gender and sexual violence, and the threat of HIV affect people's lives. As argued, acts of sexual violence are not only a form of violence against women's bodies and their mental health. Women's medical health is also threatened as sexual violence is linked to impoverishment and vulnerability to HIV and other sexually transmitted diseases.

While seeking solutions for the morally troubling issues that affect their lives, the women I interviewed turn to Mary, the mother of Jesus. Mary not only offers women solace and help, She also appears to empower women to endure their suffering. Following Mary's example, they gain confidence in the process of self-transformation into good and strong Christian wives. The women I interviewed see this transformation as empowerment - of being able to change themselves, their situations and, eventually, their husbands.

This form of empowerment refers to the process whereby women become aware of their capacity to change their lives. However, as argued by Macintyre (Ch. 8), this power has to come from somewhere. In the cases described by Macintyre, 'empowering women' often means wresting power from men so that women might represent their own interests (Ch. 8). The Catholic women I interviewed draw power from Mary. And since the effects of her power-obedience, patience, humility - are not considered problematic by men, this process does not generate conflict with them. Instead, it is often welcomed and supported, both by the male clergy and by women's husbands. 
The question is: to what extent can we view the process of becoming Mary as empowerment? When seen in the light of Foucault's notion of self-surveillance, such a form of empowerment looks very feeble. As shown, women's selfsurveillance is constituted by dominant gender relations, by the religious community - such as the members of the Legion of Mary and Church clergy like Fr Golly - and, perhaps even more importantly, by the Virgin Mary. Mary exemplifies, to use Antonio Gramsci's (1971) term 'hegemony', the quintessential 'hegemonic femininity' — a femininity that is accepted as dominant (cf. Connell 2005 [1995] on hegemonic masculinities). Mary's submissive image coincides with pre-existing gender relations and gender hierarchies, in which women's roles are constituted as being submissive to their husbands with an emphasis on their roles as caretakers of the family and as mothers. As already noted, the Church's teachings on Mary 'reflect and express the ideology of the patriarchal feminine' (Ruether 1993: 149). The virtues ascribed to Mary in the teachings of the Church and the Legion of Mary, such as silence, obedience and modesty, constitute the very essence of passive, female submission (McLauglin 1974). The advice given by clergy such as Fr Golly to abused women, urging them to stay in abusive relationships, to be patient and show forgiveness towards those who abuse them, is equally part of the hegemony and disciplinary power. In fact, it can be argued that Marian devotion and its focus on self-surveillance is actually a form of normative violence - a 'state of violence' that submits women to a violent doctrine of submission. In Foucault's terms, this doctrine of submission reduces women to docile and subjected bodies and thus seems to deny the possibility of resistance and agency.

However, as we listen to women's stories and experiences, Mary also seems to offer an escape. Mary is held up to women as a model and is appropriated by women as a model. But this model is appropriated and internalised in ways which do not always coincide with the Church's teachings or notions of the patriarchal and hegemonic female. Women like Alice and Julie not only admire Mary's virtues of patience and modesty, they also see Mary as a strong woman, as a leader. Julie, who has ambitions of being and becoming a leader herself, explains: 'Mary is a big female leader. When we women look at her, we can see our responsibilities in our family and in our communities' (Julie, Madang 2006).

Considering women's agency, we can speak in Margaret Jolly's (1992) and Holly Wardlow's terms of 'encompassed agency' (Wardlow 2006: 13). In the case of Catholic women legionaries of Mary, women's agency is not only constrained by male and social domination as described by Wardlow, but also, and perhaps more strongly, by Catholic doctrine, its clergy and Mary. In fact, one could describe women's agency in terms of 'ecclesial encompassment', as the women I interviewed exercise their agency and their creation of new subjectivities within the policed boundaries of the ecclesia. 
So Mary's role is even more ambiguous than is evident in her paradoxical role of helping women to stop violence and of facilitating a hegemonic patriarchal power which constrains women. In fact the figure of Mary as a submissive image can transform into that of a strong and powerful woman, reflected in the portrait of the worldwide leader of the Legion of Mary, the Immaculate Conception (see Figure 7). This particular image of Mary encapsulates Mary's virtues of goodness, sweetness, humility and obedience, but at the same time evinces her power to crush evil and lead an army against sin. Mary thus provides women not only with an example of how to be a good Christian mother and wife, but also how to be a strong woman leader. Mary's role as a strong woman also enables her followers, like Julie, to assume leadership positions and endure the struggle that goes with such positions and aspirations in the context of contemporary Papua New Guinean society.

This powerful dual role of Mary reflects how religious women's groups are in the foreground of changing things in PNG - including gender relations (DicksonWaiko 1999, 2003; Lee 1985; Sepoe 2000). Religious women may actively resist male domination and violation against women, urging men instead of women to change. Unlike the female members of the Legion of Mary described in this paper, who seek empowerment through individuated agency while being supported in this quest by their Legion members, women in certain other Christian groups successfully exert agency in collectives. Perhaps it is the identification with a highly individualised Mary and her personal virtues and experiences of suffering that prevents legionaries in Madang from collectively taking up arms against domestic violence. Or perhaps it was the power exerted by the Legion's spiritual director, the late Fr Golly, who confined women to their roles of docile and forgiving mothers and wives, and prevented them from acting, both collectively and individually, as warriors against the sins of men.

\section{References}

Banks, Cyndi, 2000. Contextualising sexual violence: rape and carnal knowledge in Papua New Guinea. In Reflections of Violence in Melanesia, ed. Sinclair Dinnen and Allison Ley, 83-104. Sydney: Hawkins Press and Asia Pacific Press.

Barker, John, 1990. Introduction: ethnographic perspectives on Christianity in Oceanic societies. In Christianity in Oceania: Ethnographic perspectives, ed. John Barker, 1-12. ASAO Monograph 12, Lanham,

1992. Christianity in western Melanesian ethnography. In History and Tradition in Melanesian Anthropology, ed. James Carrier, 144-73. Berkeley: Studies in Melanesian Anthropology 10. 
Borrey, Anou, 2000. Sexual violence in perspective: the case of Papua New Guinea. In Reflections of Violence in Melanesia, ed. Sinclair Dinnen and Allison Ley, 105-18. Sydney: Hawkins Press and Asia Pacific Press.

Bradley, Christine, 1994. Why Male Violence against Women. Methodological and Personal Perspectives. London: Sage Publications.

2001. Family and Sexual Violence in Papua New Guinea: An Integrated Long-term Strategy. Report to the family action committee of the consultative implementation and monitoring council. Waigani: Institute of National Affairs.

Brown, Robert Mcafee, 1987. Religion and Violence. Philadelphia: Westminster Press.

Butt, Leslie and Richard Eves, eds, 2008. Making Sense of AIDS. Culture, Sexuality, and Power in Melanesia. Honolulu: University of Hawai'i Press.

Concilium Legionis Mariae, 1993. The Official Handbook of the Legion of Mary. Dublin: Concilium Legionis Mariae. De Montforte House.

Connell, R.W., 2005 [1995]. Masculinities. Berkeley and Los Angeles: University of California Press.

Conway, Jeannette and Ennio Mantovani, 1990. Marriage in Melanesia: A Sociological Perspective. Point Series 15. Goroka: The Melanesian Institute.

Dickson-Waiko, Anne, 1999. Civil society and development, non-government organisations and churches. Development Bulletin 50 (October): 44-46.

2003. The missing rib: mobilizing church women for change in Papua New Guinea. Oceania 74(2): 98-110.

Dinnen, Sinclair, 1997. Law, order and state in Papua New Guinea. Discussion paper 1. State, Society and Governance in Melanesia Project, Research School of Pacific and Asian Studies. Canberra: The Australian National University.

Dinnen, Sinclair and Allison Ley, eds, 2000. Reflections on Violence in Melanesia. Sydney: Hawkins Press and Asia Pacific Press.

Dundon, Alison, 2010. AIDS and 'building a wall' around Christian country in rural Papua New Guinea. The Australian Journal of Anthropology 21(2): $171-78$.

Editorial, 2009. Family violence is PNG's national shame. In PNG Post-Courier, 4 June. Reprinted in Pacific Islands Report. Online: http://archives.pireport. org/archive/2009/june/06-05-ed2.htm. Accessed 20 February 2012. 
Eves, Richard, 2003. AIDS and apocalypticism: interpretations of the epidemic from Papua New Guinea. In Culture, Health \& Sexuality 5(3): 249-64.

2005. 'In God's hands': modernity, morality and illness in a Melanesian Society, paper prepared for 'Old and New Religions, Hybridisation, and the Challenge of Modernity' at the Australian Anthropological Society (AAS) Annual Conference, Adelaide, September.

2006. Exploring the Role of Men and Masculinities in Papua New Guinea in the 21st Century: How to address violence in ways that generate empowerment for both men and women. Report for Caritas Australia. Online: http://www. baha.com.pg/downloads/Masculinity\%20and \%20Violence\%20in \% 20 PNG.pdf. Accessed 28 November 2010.

2008. Moral reform and miraculous cures: Christian healing and AIDS in New Ireland, Papua New Guinea. In Making sense of AIDS: Culture, Sexuality and Power in Melanesia, ed. Leslie Butt and Richard Eves, 303-25. Honolulu: University of Hawai'i Press.

Foucault, Michel, 1997. The subject and power. In M. Foucault The Essential Works 1954-1984, Vol. III. Power, ed. J. Faubion, 326-48. New York: The New Press.

Fountain, Ossie C., 1984. Marriage the Melanesian Way. Wewak: Christian Books Melanesia Inc.

Gibbs, Philip, 2005. Political discourse and religious narratives of church and state in Papua New Guinea. SSGM Working Papers 1: 1-30.

Gramsci, Antonio, 1971. Selections from the Prison Notebooks. London: Lawrence \& Wishart.

Griffith, R. Marie, 1997. Submissive wives, wounded daughters and female soldiers: prayer and Christian womanhood in Women's Aglow Fellowship. In Lived Religion in America. Toward a History of Practice, ed. David Hall, 160-95. New Jersey: Princeton University Press.

Hahn, Scott, 2001. Hail Holy Queen. New York: Doubleday.

Hammar, Lawrence, 1999. To be young, female, and 'normal': the health risks of absent sexual citizenship. Journal of Medical Humanities 20(2): 135-54.

2007. Epilogue: homegrown in PNG - rural responses to HIV and AIDS. Oceania 77(1): 72-94. 
2008. Fear and loathing in Papua New Guinea: sexual health in a nation under siege. In Making Sense of AIDS. Culture, Sexuality and Power in Melanesia, ed. Leslie Butt and Richard Eves, 60-79. Honolulu: University of Hawai'i Press.

2010. Sin, Sex and Stigma: A Pacific Response to HIV and AIDS. Wantage: Sean Kingston Publishing.

Hermkens, Anna-Karina, 2007. The power of Mary in Papua New Guinea. Anthropology Today 23(2): 4-8.

Hermkens, Anna-Karina, Willy Jansen and Catrien Notermans, eds, 2009. Moved by Mary. The Power of Pilgrimage in the Modern World. Farnham: Ashgate.

Jebens, Holger, 2005. Pathways to Heaven: Contesting Mainline and Fundamentalist Christianity in Papua New Guinea. Oxford and New York: Berghahn.

Jenkins, Carol, 1995. Women and the risk of AIDS: A study of sexual and reproductive knowledge and behaviour in Papua New Guinea. Women and AIDS Research Program. Research Report Series 10. Washington: USAID.

Jolly, Margaret, 1992. Partible persons and multiple authors (contribution to Book Review Forum on Marilyn Strathern's The Gender of the Gift). In Pacific Studies 15(1): 137-49.

Kidu, Carol, 2000. Reflections on change, ethnicity and conflict: family and ethnic violence in Papua New Guinea. Development Bulletin 59 (November): 29-33.

Kleinman, Arthur, 1997. The violences of everyday life. The multiple forms and dynamics of social violence. In Violence and Subjectivity, ed. Veena Das, Arthur Kleinman, Mamphela Ramphele and Pamela Reynolds, 226-41. Berkeley: University of California Press.

Lee, Wendy, 1985. Women's groups in Papua New Guinea: shedding the legacy of drop scones and embroidered pillowcases. Community Development Journal 20(3): $222-35$.

Lepani, Kathy, 2008. Fitting condoms on culture: rethinking approaches to HIV prevention in the Trobriand Islands, Papua New Guinea. In Making Sense of AIDS. Culture, Sexuality and Power in Melanesia, ed. Leslie Butt and Richard Eves, 246-66. Honolulu: University of Hawai'i Press.

Malins, Ian, 1987. Christian Marriage and Family Life. Wewak: Christian books Melanesia Inc. 
Margry, Peter, 2009. Paradoxes of Marian apparitional contestation: networks, ideology, gender, and the Lady of All Nations. In Moved by Mary. The Power of Pilgrimage in the Modern World, ed. Anna-Karina Hermkens, Willy Jansen and Catrien Notermans, 183-99. Farnham: Ashgate.

McPherson, Naomi M., 2008. Sik AIDS: deconstructing the awareness campaign in rural West New Britain, Papua New Guinea. In Making Sense of AIDS. Culture, Sexuality and Power in Melanesia, ed. Leslie Butt and Richard Eves, 224-45. Honolulu: University of Hawai'i Press.

McLauglin K. Eleanor, 1974. Equality of souls, inequality of sexes: woman in medieval theology. In Religion and Sexism. Images of Woman in the Jewish and Christian Traditions, ed. Rosemary Radford Ruether, 213-66. New York: Simon and Schuster.

Mosko, Mark, 2010. Partible penitents: dividual personhood and Christian practice in Melanesia and the West. Journal of the Royal Anthropological Institute 16(2): 215-40.

National Statistical Office (NSO), 2002. Papua New Guinea Census 2000 Provincial Report-Madang. Port Moresby. The National Statistical Office.

Ram, Kalpana, 1991. Mukkuvar Women: Gender, Hegemony and Capitalist Transformation in a South Indian Fishing Community. London and New Jersey: Zed Press.

2005. Religion, gender, and the postcolonial crisis of the present: reflections on and from India. Australian Religion Studies Review 17(2): 2031.

Revival Centres of Papua New Guinea, 2005. Pamphlet for an international rally organised by the Revival Centres of Papua New Guinea in 2005.

Richert, Scott P., 2010. Pope Benedict and condoms: what he did and did not say, in Catholicism About.com, 23 November 2010. Online: http://catholicism. about.com/b/2010/11/23/pope-benedict-and-condoms-what-he-did-anddid-not-say.htm. Accessed 17 March 2011.

Robbins, Joel, 2004. Becoming Sinners: Christianity and Moral Torment in a Papua New Guinea Society. Berkeley: University of California Press.

2005. The humiliation of sin: Christianity and the modernization of the subject among the Urapmin. In The Making of Global and Local Modernities in Melanesia. Humiliation, Transformation and the Nature of Cultural Change, ed. Joel Robbins and Holly Wardlow, 43-56. Hampshire, Burlington: Ashgate Publishing. 
Ruether, Rosemary Radford, 1993. Sexism and God-Talk: Toward a Feminist Theology. Boston: Beacon Press.

Sala, H., 1999. 10-pela lo bilong marit. Wewak PNG: Christian Books Melanesia Inc.

Schmidt, Bettina E. and Ingo W. Schröder, 2001. Introduction: violent imaginaries and violent practices. In Anthropology of Violence and Conflict, ed. Bettina E. Schmidt and Ingo W. Schröder, 1-24. London: Routledge.

Seeward, Peter and Pope Benedict XVI, 2010. Light of the World: The Pope, the Church and the Signs of the Times. San Francisco: Ignatius Press.

Sepoe, Orovu, 2000. Changing Gender Relations in Papua New Guinea: The Role of Women's Organisations. India, New Delhi: UBS Publishers.

Taussig, Michael, 1993. Mimesis and Alterity: A Particular History of the Senses. New York: Routledge.

Toft, Susan, ed., 1985. Domestic Violence in Papua New Guinea. Monograph No. 3. Law Reform Commission, Papua New Guinea.

1986. Domestic Violence in Urban Papua New Guinea. Occasional Paper, No. 19. Law Reform Commission, Papua New Guinea.

Toft, Susan, 1985a. Marital violence in Port Moresby: two urban case studies. In Domestic Violence in Papua New Guinea, ed. Susan Toft, 14-31. Monograph No. 3. Law Reform Commission, Papua New Guinea.

Toft, Susan and Susanne Bonnell, 1985. Marriage and Domestic Violence in Rural Papua New Guinea: Results of a Research Project Conducted by the Law Reform Commission and Administrative College of Papua New Guinea. Port Moresby: Papua New Guinea Law Reform Commission.

Vaz, Paulo and Fernanda Bruno, 2003. Types of self-surveillance: From abnormality to individuals 'at risk'. Surveillance \& Society 1(3): 272-91.

Wardlow, Holly, 2006. Wayward Women. Sexuality and Agency in a New Guinea Society. Berkeley: University of California Press.

2008. 'You have to understand. Some of us are glad AIDS has arrived': Christianity and condoms among the Huli, Papua New Guinea. In Making Sense of Aids. Culture, Sexuality, and Power in Melanesia, ed. Lesley Butt and Richard Eves, pp. 187-205. Honolulu: University of Hawai'i Press. 
Zimmer-Tamakoshi, Laura, 1990. Sexual exploitation and male dominance in Papua New Guinea. In Human Sexuality in Melanesian Cultures, ed. J. Ingebrittson, 250-67. Point 14. Melanesian Institute, Papua New Guinea.

1997. 'Wild pigs and dog men': rape and domestic violence as women's issues in Papua New Guinea. In Gender in Cross-Cultural Perspective, ed. Caroline B. Brettell and Carolyn F. Sargent, 538-53. Englewood Cliffs, New Jersey: Prentice-Hall.

2004. Rape and other sexual aggression. In The Encyclopedia of Sex and Gender, ed. Carol Ember and Melvyn Ember, 230-43. Kluwer: Academic Press. 